\title{
The Impact of Organizational Citizenship Behavior (OCB) and Organizational Commitment on Market-Orientation of the Banks (Case Study: Parsian Bank Branches in Tehran)
}

\author{
Fariba Khoshnammoghadam ${ }^{1}$ \\ ${ }^{1}$ Kharazmi University, Iran \\ Correspondence: Fariba Khoshnammoghadam, Kharazmi University, Iran. E-mail: F.khoshnam1985@gmail.com
}

Received: July 20, 2017

Accepted: August 7, 2017

Online Published: August 12, 2017

doi:10.5539/ijbm.v12n9p173

URL: https://doi.org/10.5539/ijbm.v12n9p173

\begin{abstract}
The aim of this study was to evaluate the impact of Organizational Citizenship Behavior (OCB) and organizational commitment on market-orientation of the banks (case study: branches of Parsian bank in Tehran). The approach of the study was quantitative descriptive-survey, timely cross-sectional and the purpose was practical. The statistical society of the study were branches of the Parsian bank in Tehran, winter 2016, where based on the reason and nature of inquiry, 60 of the employees were selected as the sample size simple randomly. In addition to the standard library research, the main tools were three questionnaires that their reliability was determined 0.84 by Cronbach's alpha test. To analyze the data, descriptive and inferential statistical methods and software SPSS, version 22, was used. The results showed that OCB and also organizational commitment and its components have a significant positive impact on market-orientation of Parsian Bank.
\end{abstract}

Keywords: Citizenship behavior, organizational commitment, market-orientation of Bank, Internal marketing, Parsian Bank

\section{Introduction and Problem Statement}

In today's world as a result of economic growth and development, profound changes in the amount and quality of goods and services has emerged. Monopoly phenomenon has disappeared gradually and people (customers) freely choose the most appropriates among the products and services. This is where the competition phenomenon emerges. All institutions and organizations, both monetary and non-monetary are looking for customers to sell their goods or their services in the banks. Because their survival depends on the number of their customers. This is where the marketing in banking institutions is of such importance that a lack of interest can be viewed as the bankruptcy of that institution.

Bank marketing in the form of an operation having a scientific aspect has not a deep and long background and it is rather a new topic which its history in America, England or Japan dates back to the 1960s. Starting the spread of this concept have been too slowly, because the bankers have traditionally thought that financial needs and services does not need marketing. But from 1960 onwards, due to the changing conditions of the world economy, the banking situation was fundamentally changed and as a result, with increasing customer expectations in relation to banking services, new competition emerged between banks and to follow this pressure, the banks were forced to be market-oriented and put the marketing in the focus of their activities.

Bank marketing is strengthening potential fields and also identifying actual fields and empowering them to attract and absorb people liquidity and increase in deposits by introducing and providing banking services and directing the interests, motivations and behavior of depositors and applicants of the facilities in order to create demand, increase market share of the money, raising the level of revenue and profits and gain position for the bank (Sharifi and Hajipour, 2012).

In the last decade the behavior of individuals in the workplace has attracted the attention of scientists. The common goal in above studies is defining a kind of individual behavior that helps the long-term success of the organization (Moghimi, 2005).

On the other, organizational Commitment is an important occupational and organizational attitude that has been a 
favorite of many researchers in the fields of organizational behavior and psychology favorite in recent years (Rokni nezhad, 2007). This attitude has undergone some changes during the past three decades which perhaps the most important of this change has been in the related territory of multi-dimensional to one-dimensional approach to this concept. Also recent changes in the field of business including downsizing and mergers of companies in each other, has prompted some experts to declare that the effect of organizational commitment on other important variables in the field of management such as breach of duty, absence and performance has dropped and therefore its study is out of place (Saghravani, 2009). But some other scholars rejected this view and believe that organizational commitment has not lost its importance and can still be considered (Farhangi, 2005).

What market-orientation as a culture and as a behavior cannot occur without organizational commitment and not only top managers but also employees within the organization should also have this commitment. Therefore, the success of service organizations in the scope of market-orientation requires that employee commitment is guaranteed. One way to achieve this commitment is implementation of marketing plans (Hasangholipour et al 2012). Internal Marketing is one of the marketing topics that was introduced as an internal method to solve problems related to organization employees and to provide quality services by them two decades ago. Relevant studies on the subject indicate that internal marketing activities through influencing and motivating staffs, increase their organizational commitment, improves the organization competitiveness and promote the competencies. The main problem in this research is to study the impact of OCB and organizational commitment on banks' market-orientation in the Parsian Bank. In other words, the researchers seek to examine the impact of OCB and organizational commitment on market-orientation in the Parsian Bank.

\section{The Theory and Backgrounds}

First propounded theories about OCB was conducted by Chester Barnard in 1938. Barnard considered this behavior by expressing the concept of willingness, enthusiasm and cooperation. Some other experts believe the history of the concept of citizenship behavior traces back to the theories of Katz (1964). Katz said that effective organizations have three characteristics:

1- Maintain the employees within the system.

2- Ensure that employees do the specific requirement of their role reliably.

3- Give special attention to innovative and spontaneous activities of the employees that is beyond organizational tasks and is not considered in the job description

The third feature of effective organization from the perspective of Katz means organizations need employees with a desire to succeed beyond the minimum necessary for their jobs and certain aspects of business operations. Katz with the distinction between innovative and spontaneous performance and behavior of staffs, is among the first theory makers of OCB in the seventies and eighties. Katz counts the innovative and spontaneous behavior of employees including: cooperation with others, organization conservation, voluntary constructive ideas, self-training and maintaining a positive attitude toward organization.

The concept of OCB is a structure around the continuous interaction of the members of organizational units. The mentioned behavior strengthens the level and quality of the organizational implications in the desired direction, reduces the organization need to allocate a portion of scarce resources to perform organizational simple tasks, makes simpler the frequent keeping and retaining of employees in the organization and improves their ability for organizational effectiveness through devoting more time for planning and problem solving of employees.

Outstanding performance is not achieved through the efforts of ordinary employees, because one of the reasons of success of the large organization is that they have employees with operations beyond their official duties. Organizational citizenship behavior, is considered as an evolution in the field of organizational behavior because the mentioned concept has promoted the civil liability for innovation, flexibility, productivity, survival and more success (Sobhani et al, 2010).

The theoretical literature review shows that there are two basic approaches to define the concept of organizational citizenship behavior. Oregon (1988) and other early researchers on the subject, have studied this type of behavior as extra-role behavior. Because the activities of persons at work, is beyond the requirements of the role assigned to them, in addition, their behaviors is not honored directly and openly through formal organizational reward system.

Another group of researchers such as Graham suggests that OCB should be considered separately from work performance because in this case will not be a problem the differentiation between the role and extra-role. In the mentioned view, OCB should be considered a universal concept that includes all the positive behavior of 
employees within the organization (Moghimi, 2005).

Oregon knows the OCB a spontaneous and conscious that is not strengthened explicitly or directly by organization rewarding, but enhances the organizational effectiveness, totally. When we say spontaneous and conscious behavior, we mean in this behavior the mandatory necessity of the role is not based on the job description, but it is based on personal choice and there is no punishment in the case of not performing the task. Oregon defines OCB as a type of employee organizational behavior which promotes the effective operation of the organization carelessly to the personal exploitation aims of each employee.

Robbins and Judge believe OCB is a behavior based on personal expediency that is not a part of employee occupational requirements and indeed cause to promote the organizational effectiveness to satisfying the profits of the beneficiaries.

Vigoda et al. believe OCB include sorts of unofficial and optional helps that the employee performs or avoids them without considering sanctions and rewards as a free person.

Kim (2006) defines the OCB beyond the predefined formal roles by the organization that are inherent and their rewards are not contained directly in the formal reward structures but is of high importance in the organization promotion, effectiveness and successful operation (Vakili et al 2012).

Ashtynk (1991) believes OCB is done by people in order to help coworkers or organization and it is not in the range of their duties, certainly.

Eric and colleagues (2008) argue that organizational citizenship behavior, are activities that the person has been asked to do but doing it supports the organization and benefits it.

Mackenzie and Jean know OCB including voluntary behavior of the employees that directly increase the organizational effectiveness regardless of how the employee performance will increase (Sobhaninezhad et al, 2010).

\subsection{The Views of Experts on the Organizational Citizenship Behavior}

Despite increasing attention to the concept of organizational citizenship behavior, reviewing the literature of this area shows a lack of consensus regarding the dimensions of the concept. The results of the literature review showed that almost thirty different types of OCB was separable from each other, and numerous definitions obtained from them that of course, a lot of overlap exists between them.

\section{1- Chester Barnard's perspective on organizational citizenship behavior}

In 1930, Chester Barnard proposed the phenomenon of OCB as extra-role behaviors. He believes that individual desires for actively working to achieve organizational goals is essential. Barnard (1983) states that these efforts should not only be in the direction of achieving organizational goals; but it is necessary to be effective in the direction of protection of the organizations itself.

Barnard's (1938) performed researches on the analysis of the nature of the organization titled collaboration system. He raised some fundamental questions, such as why organizations exist? What stablishes their existence? And why is needed the perpetrators of power in organizations? In response to the importance of structure and formal control he noted to the fundamental feature of today's organizations. Although formal control structure has a lofty position in the organization, but they do not define the basic nature of cooperation systems, therefore, according to Barnard, non-formal organizations are very important and ever-increasingly these organizations have found more legitimacy.

From the above content, it can be concluded that different parts of Barnard ideas about the determinant factors of OCB has been proposed in the form of desires for cooperation. Barnard made it clear the importance and salience of people's spontaneous contributions, which are beyond contractual obligations and legal authority, in explanation of the concept of OCB more than ever.

\section{2- Katz and Kahn perspective on organizational citizenship behavior}

According to Katz and Kahn organizational citizenship behavior, mitigates the effects of the rewarding systems. The concept of OCB belongs to the readiness and willingness of people to help others that is interpreted beyond the organizational contractual obligations.

Good citizen in civil society does not simply violate the law and will not obey absolutely, of course. But upgrades the commitment and grows the sense of civil citizenship in himself and therefore feels that he should act like civil citizen base on mutual rights and respect and he be treated in the same way. Similarly, corporate employees have a similar behavior with the organization and others based on mutual rights and respect. 
Researches performed to assess OCB by Katz and Kahn, has been demonstrated that low levels of spontaneous behaviors (cooperation) source from the unreasonably wages and salary. According to Katz and Kahn, effective organizations should create three distinctive forms of participatory aids in themselves that they are as follows respectively:

1) Organizations to attract skilled people from outside their organization, in addition help to the people in the system.

2) To show the job operational capabilities and abilities based on promotion system and also the consequences of a violation of the new quality standards to the members of the organization, guarantee confidence and accordingly shape their behavior and act.

3) Organizations should develop spontaneous (cooperative) and innovative behavior

According to Katz and Kahn (1996), ultra-requirements performance, has official role for the success of the organization and some of them include assistance activities and cooperation with members of the foundation, protective proceedings, support for self-training and self-development system and a variety of great assistance that can promote spontaneous behavior.

\section{3- Smith views on organizational citizenship behavior}

Smith and colleagues (1983) argue that spontaneous behavior can be beyond organizational standards and higher than norms like reward and punishment mechanisms assist organizations and individuals in order to achieve the benefits. According to Smith, this type of behavior that are not defined in the job description of staff, could be called organizational citizenship behaviors. Smith in another definition, defines the OCB a kind of behavior that is not part of the official duties of staff, but are favorable for the organization; punctuality, helping colleagues, volunteering to do things, providing innovative proposals for progress and not waste time, are among the mentioned behaviors.

According to Smith, OCB included five areas:

- Conscientious: the behaviors that guides the person in performing his duties in slightly higher than expected levels (Person does not eat the lunch during work or do not shut his work except in urgent cases).

- Courtesy: polite behavior that prevents problem at workplace (Person tries to avoid causing problems for their colleagues and consult with them before the problem).

- Altruism: is an auxiliary behavior that is done in order to contribute to certain employees in connection with their organizational tasks and assignments (helps those with heavy work or spent his time to help those who have problems with their work)

- Sportsmanship: fair treatment that prevents lot of complaints at workplace (people do not spend their time complaining minor issues and never are fault-finding the organization).

- Civic virtue: behavior that reflects the responsible participation of the individual in organizational activities (Individual coordinate himself with organizational events or do things that are not within the scope of his duties but enhance the organization reputation.

\subsection{Theoretical Perspectives of Organizational Commitment}

\section{Meyer \& Allen Model}

Allen and Meyer (1997) believed that commitment, connects the individual with organization and this bond reduces the probability of his breach of duty (Meyer and Hrskvych, 2002)

They have offered three components of organizational commitment:

1- Affective commitment: It includes employees' emotional ties to the organization. So that people introduce themselves with their organization.

2- Continuance commitment: based on this commitment the person calculates the cost of leaving the organization. In fact, one asks if he leave, how much the organization incur. In fact, people who are committed to the organization continuously, are those who stay because they need to stay in the organization.

3- Normative commitment: In this case, the employee feels he must remain in the organization and his stay is a correct action (Luthans, 2008)

"Meyer" and "Alan" know the definitions of organizational commitment affiliate to three general issue of emotional attachment, understanding the costs and sense of duty. From the conceptual differences of the triple components of the organizational commitment, which each is somewhat independent of the others, it is 
concluded that each one is the result of special pre-opportunity. Pre-opportunity of the affective commitment are categorized to four groups: personal specification, job specification, structural specification and job experiments. Large researches that is done about organizational commitment indicates this subject that the relation of the organizational commitment with job performance and behaviors based on organizational nationality is straight (positive), but its relation with breach of duty, absenteeism and delay is inverse (negative). So the nature of the relation of the individual with organization in each of the triple component of affective commitment, continuance commitment and normative commitment is different. Employees with strong affective commitment remain in the organization because they want to stay. Those who have strong continuity commitment remain because the need to stay and those who have strong normative remain because they feel they must stay.

\section{Mayer \& Shoorman Model}

From Mayer \& Shoorman view, this two organizational commitment have two dimensions. Continuous commitment means willingness to stay in the organization, and normative commitment means doubled effort for the organization. In fact in this model continuance commitment is related to the decision to stay or leave the organization, while normative commitment is related to double efforts in the direction of gaining the organizational goals (Mayer \& Shoorman, 2000). While in Allen and Meyer models these three component of the commitment are related to the continuity of staying in the organization or leaving it.

\subsection{Jaros et al Model}

In this model, a distinction is made between three forms of affective, continuance and normative commitment. Affective commitment is based on the objective effects as experienced by employees; moral commitment is almost adaptable to affective commitment of "Meyer and Allen" and only in the case of continuance commitment their conceptual definitions matches.

\subsection{Theoretical Perspective Factors Affecting the Organizational Commitment}

Different sociological theories has been used to assess the effective factors on organizational commitment. Based on the success and value theorems of George Homans, organizational commitment is a function of work reward and work value that means if a person has a high level of commitment but do not get his expected reward, it is less likely to remain on previous commitments. Congruence between job reward (organizational and social rewards) and business value results in more organizational commitment (Karimzadeh, 1999). According to Adams' Equity Theory When employees feel that they are treated somehow unjust and unfair, proceed to activities which their goals is to reform the emotion related to fair behavior. Therefore, if the rewards offered by the organization, be fair from the perspective of employees, higher satisfaction arises because employees feel they have rewarded associated to their work and effort (Davis and Newstorm, 1991, p. 173). Therefore, the person's satisfaction affects his more or less commitment which this commitment also affects his effort and performance. Based on the Vroom's theory 3 factor of rewards value, the relation of rewards with the required performance and the required effort for performance are effective on behavior. Therefore, motivation is much affected from people's perceptions of behavioral outcomes and this can itself be affective on future behavior of the person, including his commitment (Moghimi, 1377, p. 231). According to Marshal Theory, with expansion and increase of organizational partnership in the four dimension of organization the sense of organizational belonging and harmony increases and the organizational commitment is strengthen, furthermore, organizational partnership causes increasing the person's generosity and this issue can affect people's organizational commitment (Chalapi, 2006:169). Collins believes if social harmony is weakened, then in the same amount, place, measure and kind of rights will remain unspecified and therefore, the social roles will be idiomatically blacked. In other words, expectation and commitments for activists will be dark and uncertain in the bed of social relations and cause in ambiguity of the role in the person which this role ambiguity in turn cause to a decrease in the employees commitments (Chalapi, 1996, p. 131). In the theoretical model of Moody et al in 1982 also four group of organizational commitment preconditions is explained which states the effective factors such as personality characters (age, sex, education, service records) and job characters (role ambiguity and job pressure: some roles are more difficult than others. Some of the group members have just one role, and some have different roles) that results in organizational commitment. Those who play complicated roles, usually have higher degrees but these complicated roles can insert high mental pressures on the person specially when the tasks which should be done in that role are not defined clearly or are conflicting. The pressures due to role ambiguity and role confliction is effective on the person and group organizational commitment. Based on the studies of Moody et al the role state is one of the preliminaries for establishment of commitment. The researches of Mathieu, and Zajac also confirms this subject. One of the Moody assumptions is that the state of the role is due to the obtained perception from job environment and organizational features (monitoring and control area) 
(as said Esmaiili, 2001). Moon believes that an increase in the relation of the group members with other people and groups, the commitment volume of the members will increase and so member commitments will inflated and by increasing the inflation, members commitment to other groups decreases and commitment to own group increases. Schafer believes that the amount of a person commitment is related to the amount of his needs satisfaction so the job which can satisfy the person's needs will pleased himself. Any organization based on the spiritual and mental capacity of the employees and recognition of their talents cause creation of interest to work based its nature, responsibility and commitment feeling which is in the process of the organization (Tanhayi, 2000). From the view of Fayol the principle of ordering and regulating things and humans in the organization is very important. One of the principles which is of high importance in the organization is the job constancy and stability principle in the organization. Fayol believes that for better management in the organization it is better to use people of high experience, professional and efficient. To stabilize working continuity of the experience employees in the organization, they should be managed somehow not to leave the organization. Certainly, attention to welfare and persuasion things and providing the employees development facilities etc. is among important things that leads to employees commitment to organization and if this methods is avoided the employees will not have any commitment to the manager and organization and will leave the organization quickly (Badiyi, 2009).

\subsection{Market-orientation}

Market-orientation is one of the aspects of the organizational culture which in that they employees give the biggest value to institution profitability and customer keeping via creating better value. This kind of organizational culture is under consideration as a preference of a competition that is un-mimicry, unique and valuable (Narver, J. C., \& Slater, S., 1990). Market-orientation of the organization is related to the whole of the organization as an important critical source. It is stated that market-orientation plays a basic role in the creation of direct connection between marketing and organization elements and also creation competition preference (Doayi et al, 2011). Market-orientation is defined as a part of organization culture that effectively encourages necessary behaviors in order to create excellent privilege and excellent performance valuable (Narver, J. C., \& Slater, S., 1990).

Fundamentally, two views exists about differentiable market-orientation: Behavioral perspective and cultural perspective. While the behavioral perspective describes the market-orientation based on special behaviors related to marketing for example production and propagation of the market intelligence and sensitivity of the answering to it, cultural perspective is related to the especially more fundamental characters of the organization. This tendency have been time taken for creation, is very complicated, is over the implicit experience and skills and for transformation form one company to another is very complicated if not possible (chen, Quester,2009).

\section{4 Researches in the Field of Market-Orientation}

Vast studies has been performed in the field of market-orientation in the world, which their most important was due to studies of Kohli \& Jaworski, (1993) that showed there is a positive correlation between market-orientation and business performance. Also, Narver, J. C., \& Slater, S., (1990) have investigated the relation of market-orientation with performance in the manufacturing and service industries and concluded that market-oriented institutions have better performance. Cadogan et al (2008) did the first experimental study on the relationship between market orientation and export performance. They have shown a direct relationship between export orientation and export performance exists. (Mohammedan et al., 1392).

Today, market-orientation has been the focus of many studies and articles; although there has been extensive research in this area, there is still no agreement on the true nature of market orientation. Kohli \& Jaworski offer that the concept of market-orientation is related to the extent that an organization executes marketing. Lam and his colleagues know dissemination of market orientation as a social learning process, through which market-orientation can be gained and transferred at the individual level. Extensive studies have also been conducted in the field of market-orientation results and it is recommended that the market-orientation brings benefits directly and indirectly for the organizations, among which innovation, customer loyalty, product quality and the performance of the organization is noted. Market-oriented organization are able to identify the needs and requirements of the target markets better and thus in comparison with competitors, achieves satisfaction of customers with greater efficiency and effectiveness. In this way, the organization that are market-oriented have more capabilities in achieving the organization goals such as greater market share and profit in respect to organizations that do less marketing activities.

\subsection{Internal Marketing and Market-Orientation}

Nowadays, internal marketing is known as a strategy for market-orientation. Lam and colleagues believe that market orientation is a concept of external marketing which means identifying and satisfying customer needs more effectively compared to competitors. (Jaworski \& Kohli, 1993). Bouranta and colleagues showed that internal marketing has a large positive impact on customer satisfaction and other market-orientation components. Internal marketing as a management 
technology is to solve the problems related to the efficiency of internal services, market-orientation, the successful implementation of appropriate programs and customer-orientation. Hogg and Carter (2007) defined internal marketing as an integral part of market-orientation that requires the use of marketing techniques, within an organization to create and communicate company values. Gamson counted the internal marketing as a critical part of the market-orientation.

\subsection{Internal Marketing and Organizational Commitment}

One of the important outcomes of internal marketing is increasing organizational commitment. Also, internal marketing activities increases employees' job satisfaction followed which team members play more positive role in implementing the organizational tasks. Caruana, A., \& Calleya (1998), believe that there is a relationship between internal marketing and organizational commitment. Internal marketing activities is the main tool to increase employee motivation, organizational commitment and employee satisfaction. Lings believes internal marketing has a positive impact on the internal aspects of organizational performance such as employee satisfaction, employee protection and employee commitment. Another study suggests that hospital administrators can use increase employees' perceptions of organizational commitment with internal marketing activities. Also the results of the study of using internal marketing in bank branches, showed internal marketing has a positive effect on organizational commitment. Farzad and colleagues examined the importance of internal marketing on organizational commitment in the field of Iranian's financial services. Hung \& Lin suggested that employees understanding of the internal evaluation in management systems, has positive impact on their organizational commitment on Taiwan's international hotel industry.

\subsection{Internal Marketing and Organizational Citizenship Behavior}

Very few studies have examined the relationship between internal marketing and organizational citizenship behavior. Among these studies Souchon and Lings (2001) believe that the adoption of internal marketing activities affects the OCB and employee retention. Huang and Lin (2008) suggested that in the international hotel industry staff's understanding of internal marketing has direct impact on OCB and staff retaining. Kazemeyni (2010) examined the effects of internal marketing on OCB and its relationship with quality of service in branches of Saman Bank and came to the conclusion that internal marketing activities has a positive impact on organizational citizenship behaviors via employees.

\subsection{Organizational Commitment and Citizenship Behavior}

Organ (2000) believes the amount of employee commitment to the organization can be effective in the organizational citizenship behavior's appearance or type. Organizational commitment is an attitude that implies this point that the organization members to what extent adapt themselves to and involve in the organization whey work. A person who has high organizational commitment, remain in the organization, accepts its objectives and to achieve those objectives, shows too much effort or even sacrifices.

Job attitudes (job satisfaction and organizational commitment) are accounted as predictors of organizational citizenship behaviors. Pauline and colleagues (2006) concluded that the commitment has a significant relationship with organizational citizenship behaviors and behaviors of customers. Cohen (2006) examined the relationship between multiple commitments of organizational commitment, job commitment, job involvement and group, ethnicity and cultural values commitment with OCB and inter role performance, and came to the conclusion that organizational commitment, group commitment and job involvement in comparison with job commitment are more related to organizational citizenship behaviors and inter-role performance. Bonaparte (2009) examined how OCB is under the influence of organizational commitment and concluded that organizational citizenship behaviors has a positive relationship with organizational commitment. Hung \& Lin (2008) with the findings that organizational commitment has a positive effect on organizational citizenship behaviors support most of these studies.

\subsection{Organizational Commitment and Market-Orientation}

In the studies that have been performed in the field of organizational commitment, it seems that there is no agreement in whether organizational commitment is an antecedents or consequence of market-orientation. Waris (2006) generally studding market-orientation and organizational commitment, found a positive relationship between the two variables. Siva Rama Krishna et al suggested that organizational commitment is one of the antecedents of market-orientation, such that for a market-based reward system it is necessary to develop the market orientation culture. They also concluded that organizational commitment has a direct impact on organizational orientation. Jones et al (2003) believe that organization sellers' understanding of the market-orientation, results in increasing of their organizational commitment.

\subsection{OCB and Market-Orientation}

Researchers believe that $\mathrm{OCB}$ can be considered as a consequence of market orientation that uses the three dimension of Narver \& Slater (Customer-oriented, competition-oriented and inter-sectoral coordination) for measuring market-orientation. For example Kasōg (2007) suggested that market-orientation can have a positive effect on organizational citizenship behavior. Also, Waris (2006) by investigating the parameters of employees' attitude to 
organizational commitment and perception of the workplace found a positive relationship between market-orientation (customer orientation, competitiveness and cross-sectoral coordination) and organizational citizenship behavior.

\subsection{Research Backgrounds}

Hasangholipour and colleagues (2012) in a study titled (study of the effect of internal marketing in service organization with emphasis on the role of the mediator of OCB and organizational commitment, Bank Mellat survey, Tehran, Iran) showed that: 1 . There is a positive and meaningful relation between internal marketing and market-orientation in Bank Mellat in Tehran. 2. There is positive and meaningful relation between internal marketing and organizational commitment in Bank Mellat in Tehran. 3. There is a positive and meaningful relation between internal marketing and OCB in Bank Mellat in Tehran. 4. There is a positive and meaningful relation between organization commitment and OCB in Bank Mellat in Tehran. 5. There is a positive and meaningful relation between organizational commitment and market-orientation in Bank Mellat in Tehran. 6. There is a positive and meaningful relation between OCB and market-orientation in Bank Mellat in Tehran.

Seyed Javadin and colleagues (2007) have carried out a research titled (internal marketing, a step to improve OCB and quality of service). In this study vision, develop and reward as three original factors and observable variables, are used for measuring the hidden variable of internal marketing. Sarmad Saeedi and Jamshidian (2013) have performed a study titled (Investigation the effect of internal marketing on market-orientation and the performance of the service organizations, Case study of the branches of Refah Bank in the Arak city) where the result of this study indicates the positive effect of internal marketing on organizational commitment, organizational citizenship behavior, market-orientation and organizational performance.

Also, results of the study of using internal marketing in bank branches showed that internal marketing has a positive effect on organizational commitment (Kyriazopoulos et al, 2007).

Souchon and Lings believe adoption of activities of internal marketing is effective on organizational citizenship behaviors and employee retaining in organization (Souchon \& Lings, 2001).

Hung and Lin proposed that in International Hospitality Industry staff understanding of internal marketing has a direct effect on OCB (Hung \& Lin, 2008).

Waris found a positive relationship between market orientation (customer orientation, competitor orientation and inter-sectoral coordination) and $\mathrm{OCB}$ via studying the employee attitudes to organizational commitment and perception of workplace variables (Waris, 2006).

\subsection{Research Goal}

The goal of the research is investigation the effect of OCB and organizational commitment on market-orientation of the banks (Case Study: Parsian Bank branches in Tehran)

\section{Hypotheses}

1- Organizational commitment has a meaningful effect on market-orientation of the banks

2- affective commitment has a meaningful effect on market-orientation of the banks

3- Continuance commitment has a meaningful effect on market-orientation of the banks

4- normative commitment has a meaningful effect on market-orientation of the banks

5- OCB has a meaningful effect on market-orientation of the banks 


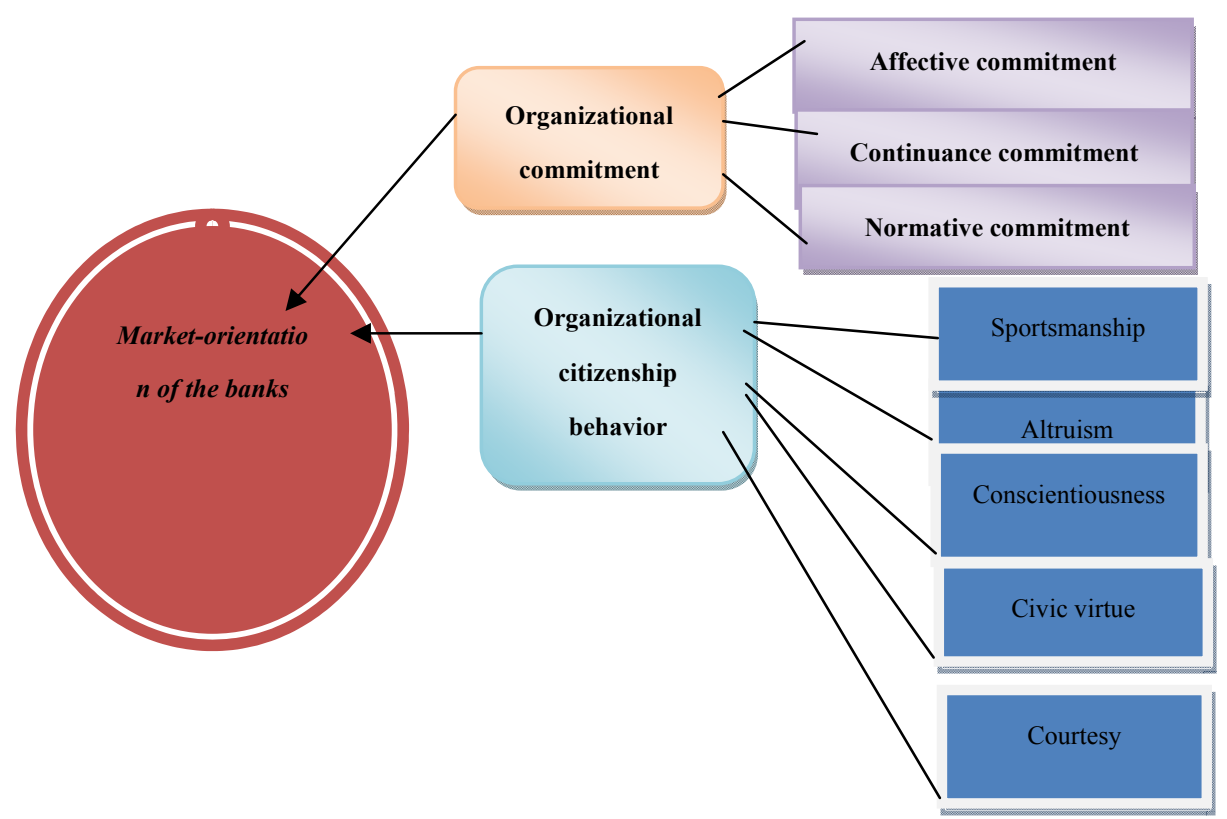

Figure 1- conceptual model of the study

\section{Methodology}

The approach of this study is quantitative (descriptive survey) from the branch of correlation (regression) and cross-sectional and is an applied research. Statistical society of the research were the staff of the Parsian bank branches in Tehran, of which 60 were selected as sample. The main tools were three questionnaires which their validity and reliability was approved in previous researches. In this study those questionnaire were evaluated form the point of

Reliability using the Cronbach's alpha test which was 0.84 and shows that the reliability of the questionnaire is enough. Version 22 of SPSS software was used for analyzing the data.

\section{Findings}

\subsection{Descriptive statistics}

Table 1. Frequency Table of sample by gender

\begin{tabular}{lll}
\hline Percent & Number & Gender \\
\hline 33.3 & 20 & female \\
66.7 & 40 & male \\
$100 \%$ & 60 & total \\
\hline
\end{tabular}

The data of the table 1 , shows that from a total of 60 sample 20 persons ( 33.3 percent) are women and 40 person (66.7 percent) are men. (The greatest gender group are men).

Table 2. The age variable of the samples

\begin{tabular}{lll}
\hline Percent & Number & Age variable \\
\hline 16.7 & 10 & 20 to 30 years-old \\
41.7 & 25 & Between 30 and 40 years-old \\
33.3 & 20 & 40 to 50 years-old \\
8.3 & 5 & Over 50 years-old \\
$100 \%$ & 60 & Total \\
\hline
\end{tabular}


The above data indicate the age variable of the present individual in the sample survey which shows that 10 persons $(16.7 \%)$ of them are in the age group of 20 to 30 years-old. And 25 persons $(41.7 \%)$ of them are in the age group of 30 to 40 years-old and 20 persons (33.3\%) of them are in the age group 40 to 50 years-old. Also, 5 persons $(8.3 \%)$ are in the age group over 50 years-old. The table's data shows that the largest age group is the people of 30 to 40 years- old and the least age category is above 50 years-old.

Table 3. Work experience variable of the research samples

\begin{tabular}{lll}
\hline Percent & Number & Work experience \\
\hline 16.7 & 10 & 1 to 10 years \\
41.7 & 25 & 10 to 20 years \\
33.3 & 20 & 20 to 25 years \\
8.3 & 5 & Over 25 years \\
$100 \%$ & 60 & Total \\
\hline
\end{tabular}

According to the above data (Table. 3), 10 persons (16.7\%) of the sample had a work-experience of 1 to 10 years. 25 persons $(41.7 \%)$ had 10 to 20 years of experience and 20 persons (33.3\%) had a work experience of between 20 and 25 years and also 5 persons had a work experience of above 25 years.

Table 4. Education variable of the persons in this survey

\begin{tabular}{lll}
\hline percent & Number & Education \\
\hline 16.7 & 10 & Diploma \\
6.7 & 4 & Associate Degree \\
66.7 & 40 & Bachelor \\
10.0 & 6 & Master's degree or higher \\
$100 \%$ & 60 & Total \\
\hline
\end{tabular}

According to the above data (Table. 4) 10 persons (16.7\%) have a diploma degree, 4 persons (6.7) have an associate degree, 40 persons $(66.7 \%)$ are bachelor and also 6 persons $(10 \%)$ have master or higher degree.

\subsection{Test of the Hypotheses}

Table 5. Regression testing for the hypotheses

\begin{tabular}{|c|c|c|c|c|}
\hline $\mathbf{F}$ & $\beta$ & P (Statistical significance) & $R^{2}$ & $\boldsymbol{H}$ \\
\hline 85.475 & 0.137 & 0.000 & 0.549 & 1 \\
\hline 38.226 & 0.154 & 0.001 & 0.502 & 2 \\
\hline 98.940 & 0.125 & 0.000 & 0.591 & 3 \\
\hline 33.548 & 0.114 & 0.001 & 0.558 & 4 \\
\hline 36.217 & 0.195 & 0.000 & 0.606 & 5 \\
\hline
\end{tabular}

As in the above table the statistical significance is less than $5 \%$, the research hypothesis is confirmed. It can be said that two variables organizational commitment and market-orientation correlates together. Waris (2006) and Siva Rama Krishna et al (2008) also achieved similar results. Also, it can be said that the two variable OCB and market-orientation are correlated.

\section{Discussion and Conclusion}

Organizational commitment is an important occupational and organizational attitude which have been interested during the past years by organizational behavior and psychology, particularly social psychology researches. Today, human resources are viewed as the most important resource in organizations and managers have found that the most important factor in competitive advantage are human resources; Hence, nowadays attention to the issue of commitment and loyalty of human resources to organization and better performing the assigned roles and even extra-role duties by human resources is one of the serious concerns of the organizations' managers. Organizational commitment is an attitude. It is a mental state that represents a kind of tendency, need and necessity to continue the 
occupation in an organization. That willingness means individual's interest and heart's desire to continue serving in the organization, need means the person have to continue to serve in the organization because of the investments he have done there, and obligation is debt, responsibility and duty that person has against the organization and commit himself in staying. From another perspective organizational commitment is a sense of connection and dependence to the organization.

So, organizational commitment is "an attitude about the loyalty of the employees to the organization" and is an ongoing process through which members of the organization show their interest to the organization and its success and continues performance.

Obviously, organizational commitment of the employees would be valuable when have positive effect on the organizational excellence and improves the productivity of the organization.

The main results of the employee's commitment to organization which also affects the organization performance are: increasing the creativity and innovation of employees, increasing employee retention in the organization, satisfaction, attachment, employees dependency on and attachment to the organization, improving their job performance, reduce turnover from organization, active social behavior, lack of absence from work, altruism and helping colleagues and reducing job stress and also gaining organizational financial success and increase the effectiveness and efficiency of the organization that these results finally leads to the elevation and gaining organizational goals and benefits the society from the profit of the organization and efforts of the employees. Affective commitment, continuance commitment and normative commitment have a direct, positive and meaningful influence on the inner market-orientation of the bank.

Executing inner marketing politics in bank will strengthening the job commitment, citizenship behaviors and occupation satisfaction of the employees. Occupation satisfaction of the employees finally leads to emerging behaviors that is favorable for the bank. Thus, their citizenship behavior will effected by their satisfaction. So, if bank managers are interested to stablish a specific and desired type of citizenship behavior in the bank, they should strive both in increasing the job satisfaction of employees and also in more than ever considering their mutual operation. Bank managers should try to increase the spirit of cooperation and partnership of the employees by participating them in the bank meetings and exerting their suggestions and views, because employee participation in the goal-setting, decision-making and carrying out banking activities results in build and strengthen of their trust, confidence and satisfaction is in the bank. When there is a cohesion between the employees of an organization and the goal of the organization is more preferred than the personal goals, then requests of the customers of the organization are a priority and are focused. It could be concluded that, when the Organizational Citizenship Behavior (OCB) arises among bank staff, customer orientation and attention to customers' demands will become a priority and staffs try harder to keep customers satisfied. Banks can establish more friendly social relations between themselves and customers by training their staff and establish a deeper understanding of the real needs of customers and intimate atmosphere for the customers.

Souchon \& Lings (2001) believe that the adoption of internal marketing is effective on OCB and employee retention. Hung and Lin (2008) suggested that the international hotel industry, staff's understanding of internal marketing has a direct impact on OCB and retaining staff. Kazemeini (2010) examined the effects of internal marketing on OCB and its relationship with quality of service in branches of Saman bank and came to the conclusion that internal marketing activities of the employees has a positive impact on organizational citizenship behaviors.

Organ knows the OCB by the staffs a positive action to improve productivity, correlation and cohesion of workplace that are beyond the organizational requirements. Organ in his review also considered the fact that avoiding hurting and lack of institutional harassment in the workplace is very important, although, among the various forms of expression of OCB is less considered. Organ defines OCB an individual behavior in the organization that promotes organizational effectiveness.

\section{References}

Alvani, M. (2007). General Management (31st ed.). Tehran: Ney Publishing.

Aula, P., \& Siira, K. (2010). Organizational Communication and Conflict Management Systems A Social Complexity Approach. Nordicom Review, 31, 125-141. https://doi.org/10.1515/nor-2017-0125

Baker, P. (2007). The Relationship between the Congruence of Physician Compensation Plan Componentsand Physician. Ph.D Dissertation, Walden University.

Baylor, T., \& Jessie, L. (2002). Factors Influencing Physician Participation in Medicaid in the USA. Interna Tionat Journal of Social Economics, 29(9), 753-762. https://doi.org/10.1108/03068290210438068 
Berger, P. D., Eechambadi, N., George, M., Lehmann, D. R., Rizley, R., \& Venkatesan, R. (2012). From customer lifetime value to shareholder value: theory, empirical evidence, and issues for future research. Journal of Service Research, 9(2), 156-167. https://doi.org/10.1177/1094670506293569

Bloom, M., \& Michel, J. (2002). The Relationships among Organization Context.

Carrell, M. R., \& Kuzmits, F. E. (1988). Personnel, Human Resource Management (2nd ed.).

Caruana, A. (2002). Service loyalty: The Effects of Service Quality and the Mediating Role of Customer $\begin{array}{llll}\text { Satisfaction. European Journal of } & \text { Marketing, }\end{array}$ https://doi.org/10.1108/03090560210430818

Chan, H., \& Wan, L. C. (2012). Consumer responses to service failures: a resource preference model of cultural influences. Journal of Marketing Research, 16(1), 72-97.

Cheng, S. C., \& Lam, T. (2012). The role of the customer-seller relationship in the intention of the customer to complain: A study of Chinese restaurateurs. International Journal of Hospitality Management, 27, 552-562. https://doi.org/10.1016/j.ijhm.2007.07.030

DeConnick, J. B., \& Stilwell. (2004). Incorporating organizational justice, role states, pay in a model of turnover intentions. Journal of business research, satisfaction and supervisor, 57, 225-231. https://doi.org/10.1016/S0148-2963(02)00289-8

Doppler, E., Harkins, D. A., \& Mehta, C. M. (2008). Emerging Empowerment: Conflict Resolution Intervention and Preschool Teachers' Reports of Conflict Behavior. Early Education and Development, 19, 885-906. https://doi.org/10.1080/10409280802516058

Elahi, S., \& Heidari. (2006). Customer relationship management. Chap and Nashr Comp, (1).

Fredrick, A. F., \& Mukesh, U. (2000). Interservqual-an Internal Adoption of the GAP Model in a Large Service Organization. Journal of Service Marketing, 14(5), 358-377. https://doi.org/10.1108/08876040010340991

Ghafari, A. P., Mousavi, B. S., Ghahari, B., \& Mahmoudvand, Z. (2009). The role and effectiveness of oral advertising and viral marketing, newspaper management. Covenant managers.

Gray, B., Coleman, P. T., \& Putnam, L. L. (2007). Intractable conflict: New perspectives on the causes and conditions for change. American Behavioral Scientist, 50(11), 1415- 1429. https://doi.org/10.1177/0002764207302459

Haghighi, M, (2003). Loyalty service: service quality effects and the role of customer satisfaction. Knowledge Management, 61-60, 53-72.

Henderson, R. I. (2006). Compensation Management in a Knowledge Based-World. New Jersey: Prentice-Hall.

Heneman R. L., Greenberger D. B., \& Fox J. A. (2002). Pay increase satisfaction. Human Resource Management Review, 12, 74-63.

Heneman, H., \& Judge, T. A. (2009). Compensation Attitudes. In Rynes, S. L. and Gerhart, B. (Eds.), Compensation in Organizations: Current Research and Practice. Jossey-Bass, San Francisco, CA, pp. 61-103. https://doi.org/10.1016/S1053-4822(01)00041-9

Horton, F. T., \& Hicks, D. L. (2006). Productivity Based Compensation: Magic Bullet Vs Poison Pill. Group Practice Journal, 36-39.

Host, V., \& Knie-Andersen, M. (2004). Modeling Customer Satisfaction in Mortgage Credit Companies. International Journal of Bank Marketing, 22(1), 26-39. https://doi.org/10.1108/02652320410514915

Kardgar, M. J. (n.d.). Identifying and ranking the most important factors affecting customer loyalty Maskan Bank using multi-criteria decision-making methods", thesis Shahid Beheshti University. Faculty of Management and Accounting.

Karroubi, M., \& Yosefi, J. (2010). To compare the perceptions and expectations of guests to the five dimensions of service quality in the hospitality industry (Case Study 2 Homa Hotel Mashhad). Journal of Tourism Studies, (13).

Makki, Z. V., Hajkrymy, A. A., \& Jmalyh, B. B. (2009). Investigaion the relationship between quality of service and customer loyalty in the face of business services. Management Perspective, 33.

Robert, H. L. (2009). The Impact of Changes in Payment Methods on the Suply of Physicians. 
Rui, L. (2005). Impact of Financial Incentives on Physician Productivity in Medical Groups. Ph.D Dissertation: University of California.

Rundell, A. G., \& Gomez-Mejia, L. R. (2002). Power as a Determinant of Executive Compensation. Journal Human Resource Management Review, 12, 3-23. https://doi.org/10.1016/S1053-4822(01)00038-9

Rynes, S. L., Gerhart, B., \& Parks. L. (2005). Personnel Psychology: Performance Evaluation and Pay for Performance. Review in Advance, 56, 571-600. https://doi.org/10.1146/annurev.psych.56.091103.070254

Sayed J, R., Farahi, M., \& Taheri, A. G. (2010). Recognizing the impact of organizational justice dimensions on job satisfaction and organizational aspects. Journal of Business Administration, 1(1).

Shieh, C. J. (2008). Effect of Corporate Compensation Design on Organization Performance. Social Behavior and Personality, 36(6), 827-840. https://doi.org/10.2224/sbp.2008.36.6.827

Shittu, O. (2008). Pay Referent Comparison and Pay Level Satisfaction Some Differences among Employees in the UK food Retail Sector Business School. Barking College, Romford, Essex. Management Research News, 31(7). https://doi.org/10.1108/01409170810876099

Syed, J. R. (2006). Factors affecting customer loyalty Export Development Bank of Iran using the concepts of Customer Relationship Management. Business Review, 18, 91-82.

Tabatabai, H. V., \& Akhavan, N. (2010). The relationship between internal marketing and service quality: A Case Study of Agricultural Bank. National Conference on Challenges of leadership and management in Iranian organizations, Islamic Azad University, Science and Research Branch of Isfahan.

Taghipour, A., Dezhban, R., Khadem Dezfoli, Z., \& Anami, A, (2011). The relationship between communication skills and conflict resolution styles of managers with employee empowerment. Social Psychological Research, 1(2).

Youssefi, P. (2006). Factors influencing customer loyalty Export Development Bank of Iran using the concepts of customer relationship management", Second International Conference on Information and Communication Technology Management, Tehran - Nedaye Eghtesad Bamdad, (Nab).

\section{Copyrights}

Copyright for this article is retained by the author(s), with first publication rights granted to the journal.

This is an open-access article distributed under the terms and conditions of the Creative Commons Attribution license (http://creativecommons.org/licenses/by/4.0/). 